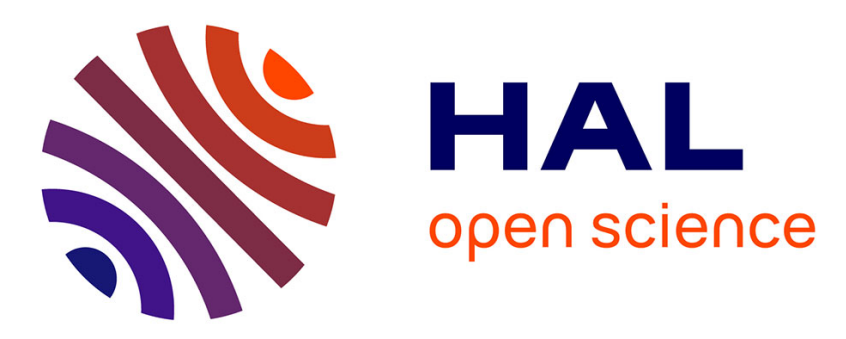

\title{
Mass Proportion of Microaggregates and Bulk Density in a Brazilian Clayey Oxisol.
}

Nathalie Volland-Tuduri, Ary Bruand, Michel Brossard, Luíz Carlos Balbino, Maria Inês Lopes de Oliveira, Éder de Souza Martins

\section{To cite this version:}

Nathalie Volland-Tuduri, Ary Bruand, Michel Brossard, Luíz Carlos Balbino, Maria Inês Lopes de Oliveira, et al.. Mass Proportion of Microaggregates and Bulk Density in a Brazilian Clayey Oxisol.. Soil Science Society of America Journal, 2005, 69, pp.1559-1564. 10.2136/sssaj2003.0344 . hal00022692

\section{HAL Id: hal-00022692 \\ https://hal-insu.archives-ouvertes.fr/hal-00022692}

Submitted on 12 Apr 2006

HAL is a multi-disciplinary open access archive for the deposit and dissemination of scientific research documents, whether they are published or not. The documents may come from teaching and research institutions in France or abroad, or from public or private research centers.
L'archive ouverte pluridisciplinaire HAL, est destinée au dépôt et à la diffusion de documents scientifiques de niveau recherche, publiés ou non, émanant des établissements d'enseignement et de recherche français ou étrangers, des laboratoires publics ou privés. 


\title{
Mass Proportion of Microaggregates and Bulk Density in a Brazilian Clayey Oxisol
}

\author{
Nathalie Volland-Tuduri ${ }^{\mathrm{a}, *}$, Ary Bruand ${ }^{\mathrm{a}}$, Michel Brossard ${ }^{\mathrm{b}}$, Luíz Carlos \\ Balbino $^{\mathrm{c}}$, Maria Inês Lopes de Oliveira ${ }^{\mathrm{d}}$, Éder de Souza Martins ${ }^{\mathrm{d}}$. \\ ${ }^{a}$ Institut des Sciences de la Terre d'Orléans (ISTO), UMR 6113 CNRS-UO, Université \\ d'Orléans, Géosciences, BP 6759, 45067 Orléans Cedex 2, France. \\ ${ }^{b}$ IRD, BP 64501, 34394 Montpellier Cedex 5, France. \\ ${ }^{c}$ EMBRAPA Arroz e Feijão, C.P. 179 - CEP 75.375-000 Santo Antônio de Goiás - GO, \\ Brazil. \\ ${ }^{d}$ EMBRAPA Cerrados, C.P. 08223, 73301-970 Planaltina-DF, Brazil.
}

\section{*Correspondance}

Nathalie.Volland@univ-orleans.fr

Ary.Bruand@univ-orleans.fr

brossard@ird.mpl.fr

balbino@cnpaf.embrapa.br

eder@cpac.embrapa.br 


\title{
Mass Proportion of Microaggregates and Bulk Density in a Brazilian Clayey Oxisol
}

\begin{abstract}
The physical properties of Brazilian Oxisols are closely related to the development of their microstructure, which typically consists of stable microaggregates smaller than 1 $\mathrm{mm}$. There is no model available to predict changes in microstructure in Oxisols. The objective of this work was to relate the proportion of microaggregates to the bulk density $\left(D_{\mathrm{b}}\right)$ in the soil studied. Five sites of a typic Haplustox under native vegetation (two sites) and pasture (three sites) were sampled. Soil bulk density, sand, silt, and clay content and aggregate size distribution were measured from the surface to $1.6 \mathrm{~m}$ deep in increments of $0.1 \mathrm{~m}$. Thin sections were prepared from undisturbed samples collected in duplicate from 0-0.1 m, 0.3-0.4 m, 0.8-0.9 $\mathrm{m}$ and 1.5-1.6 $\mathrm{m}$ depth, and backscattered electron scanning images (BESI) were generated. Clay content ranged from 672 to $798 \mathrm{~g} \mathrm{~kg}^{-1}$ and bulk density between 0.87 and $1.18 \mathrm{~g} \mathrm{~cm}^{-3}$ among the 80 samples studied. $D_{\mathrm{b}}$ was poorly correlated with clay content $\left(R^{2}=0.358\right)$ and at any depth was not significantly smaller under native vegetation than under pasture. Visual assessment of BESI revealed that soil material corresponded to either microaggregates $(<0.1 \mathrm{~mm})$ in loose arrangement or to much larger aggregates. Quantification of BESI from the deepest sampling depth of all soils showed that 96.2 and $95.7 \%$ of microaggregates were $<0.8 \mathrm{~mm}$ with 73.2 and 95.7 $\%$ between 0.1 and $0.5 \mathrm{~mm}$ under native vegetation and pasture, respectively. The mass proportion of microaggregates can be estimated using the $<0.84 \mathrm{~mm}$ soil material that is obtained by dry sieving $(\Phi<0.84)$. Finally, our results showed that $\Phi<0.84$ varied with $D_{\mathrm{b}}$. Linear regression coefficients were calculated for the relationship between $\Phi<0.84$ and the reciprocal of bulk density $\left(1 / D_{\mathrm{b}}\right)\left(\Phi<0.84=1.97\left(1 / D_{\mathrm{b}}\right)-1.52, R^{2}=0.82\right)$, assuming no interaction between microaggregates and macroaggregates, the porosity of these two structural types was estimated as 0.71 and 0.51 , respectively.
\end{abstract}




\section{INTRODUCTION}

Due to the lack or minimal development of macrostructure, the physical properties of most Oxisols in Brazil are closely related to their microstructure, which usually consists of very stable microaggregates 0.08 to $0.20 \mathrm{~mm}$ in size (e.g. Lima and Anderson, 1997; Furian et al., 1999; Neufeldt et al., 1999). Therefore and despite the small development of macrostructure, the bulk density $\left(D_{\mathrm{b}}\right)$ under native vegetation is usually lower than in many other Brazilian soils (Camargo et al., 1988; Brossard et al., 1997). Values of $D_{\mathrm{b}}<1$ $\mathrm{g} \mathrm{cm}^{-3}$ are common in Oxisols with a strong microstructure (Bernoux et al., 1998; Neufeldt et al., 1999). When land is cleared for pasture or more intensive agricultural usage, the structure is usually altered and results in an increase in $D_{\mathrm{b}}$ (Stone and Da Silveira, 1978; Curmi et al., 1992; Tavares-Filho and Tessier, 1998; Kondo and Dias Junior, 1999). When the soil is cultivated, macropores that resulted from biological activity under native vegetation are the first to disappear, particularly in the topsoil (Borges et al., 1999). Tavares Filho (1995) studied tilled clayey Oxisols developed on basalts in southern Brazil and showed that macroaggregates development both in topsoil and subsoil was increased by management practices. This was also observed by Balbino et al. (2001 and 2004) as well as a decrease in microaggregates development in Brazilian clayey Oxisols on clearing for pasture. This was interpreted as resulting from a change in the faunal activity in the soil. Neufeldt (2001) showed that under a low productivity pasture, $D_{\mathrm{b}}$ was $1.2 \mathrm{~g} \mathrm{~cm}^{-3}$ at $0-0.1 \mathrm{~m}$ depth, compared with $<1.1 \mathrm{~g} \mathrm{~cm}^{-3}$ at the same depth under native vegetation. On the other hand, Lilienfein et al. (1999) compared $D_{\mathrm{b}}$ of Savana Oxisols in Brazil and did not record any significant difference at 0-0.1 m depth between the soil under native vegetation and under degraded pasture. Finally, Desjardins et al. (2004) studied the effect of forest conversion to pasture on soil carbon content in Brazilian Amazonia. They did not record any variation of $D_{\mathrm{b}}$ after 15 years of pasture in a clayey Oxisol, but an increase of about $0.2 \mathrm{~g} \mathrm{~cm}^{-3}$ in a sandy clayey Oxisol.

Numerous studies in the literature have related $D_{\mathrm{b}}$ to some combination of sand, silt, clay, organic matter content, water retention at $-1500 \mathrm{kPa}$, including sometimes depth and $\mathrm{CaCO}_{3}$ content (Alexander, 1980; Rawls, 1983; Manrique and Jones, 1991; Prevost, 2004). Bernoux et al. (1998) studied 62 Brazilian Oxisols and also found that $D_{\mathrm{b}}$ was 
closely related to clay and organic carbon content $\left(\mathrm{R}^{2}=0.71\right)$. Finally, Calhoun et al. (2001) developed pedotransfer functions for $D_{\mathrm{b}}$ using a data set of 987 horizons from Ohio soils. They showed that using a combination of continuous variables (laboratory data) and nominal variables (site/state factor and morphological class description) significantly improves prediction of $D_{\mathrm{b}}$. This improvement can be explained by the residual variation of $D_{\mathrm{b}}$ within classes combining particle size distribution (sand, silt and clay content) and organic carbon content, particularly in topsoils because of variation related to soil use and its consequences on soil structure development (Neves et al., 2003). According to Calhoun et al. (2001), when soils developed in the same parent material and exhibit similar texture, $D_{\mathrm{b}}$ is mainly related to the development of the structure. The objective of this study was to relate the mass proportion of microaggregates to $D_{\mathrm{b}}$ for the soil studied.

\section{MATERIALS AND METHODS}

\section{Site Characteristics}

The study site is located in the Brazilian Savannah biome (Cerrado) on a farm (Fazenda Rio de Janeiro), $15 \mathrm{~km}$ north of Planaltina de Goiás $\left(15^{\circ} 14^{\prime} \mathrm{S}, 47^{\circ} 42^{\prime} \mathrm{W}\right)$ in the state of Goiás. The native vegetation is a xeromorph forest (Cerradão) with most trees less than $20 \mathrm{~m}$ high. Most of the area was cleared in the last 20 years. The elevation at the site ranges from 780 to $810 \mathrm{~m}$. The mean annual temperature is $22^{\circ} \mathrm{C}$ and the mean annual rainfall is $1100 \mathrm{~mm}$ with less than $100 \mathrm{~mm}$ over the period from May to September.

The soils are Typic Haplustox in the U.S. Soil Taxonomy (Soil Survey Staff, 1996) or Latossolo Vermelho according to the Brazilian classification (Embrapa, 1999). They developed in deeply weathered Meso-neoproterozoic metasedimentary rocks (Paranoá Group), which are conglomerates topped by quartzite and metasiltite (Freitas-Silva and Campos, 1998). Balbino et al. (2002a) studied Oxisols in the same area and found that the soils show little or no distinct horizonation. They also found that the macrostructure is weak to moderate and they have typically a strong microstructure with near spherical microaggregates from 0.05 to $0.50 \mathrm{~mm}$ in size. Balbino et al. (2002a) also found that the clay content ranges from 700 to $800 \mathrm{~g} \mathrm{~kg}^{-1}$, the bulk density from 0.8 to $1.2 \mathrm{~g} \mathrm{~cm}^{-3}$. They 
showed that the organic carbon content is $<30 \mathrm{~g} \mathrm{~kg}^{-1}$ in the surface horizons under native vegetation.

Two soils under native vegetation (NV1 and NV2) were selected at two locations along a $700 \mathrm{~m}$ long slope with a 5\% gradient. The soils NV1 and NV2 were located approximately upslope and in the middle of the slope, respectively. Three soils under a pasture of Brachiaria brizantha cv. Marandú (BRA-000591, CIAT 6294) were selected: a 13 year-old pasture (PA1), a 10 year-old pasture (PA2) and a 2 year-old pasture (PA3). The soil PA2 on one hand and PA1 and PA3 on the other hand were at similar location along the slope than the soils NV1 and NV2, respectively. The five soils were located within a quadrilateral area of about $1 \mathrm{~km}^{2}$.

\section{Soil sampling and methods}

We sampled five pits in April 2002. A single sample was collected every $0.1 \mathrm{~m}$ from the surface down to $1.6 \mathrm{~m}$ depth, air-dried and passed through a $2 \mathrm{~mm}$ sieve prior to organic carbon and particle size distribution analysis. Organic carbon contents are not discussed in this article. For the samples collected from 0 to $0.4 \mathrm{~m}$ depth, organic matter was removed with $\mathrm{H}_{2} \mathrm{O}_{2}$ prior to dispersion. The soil was dispersed by adding $10 \mathrm{~g}$ of $<2$ $\mathrm{mm}$ soil to $100 \mathrm{ml}$ of water with $10 \mathrm{ml}$ of $\mathrm{NaOH}\left(40 \mathrm{~g} \mathrm{~L}^{-1}\right)$ and $10 \mathrm{ml}$ of $\mathrm{Na}$ hexametaphosphate solution (50 g of hexametaphosphate with $7 \mathrm{~g}$ of $\mathrm{Na}_{2} \mathrm{CO}_{3}$ in $1 \mathrm{~L}$ of deionised water) (Camargo et al., 1986; Balbino et al., 2001). After resting 10 hours, the suspension was mechanically agitated overnight. Fractions smaller than $0.002 \mathrm{~mm}$ and from 0.002 to $0.02 \mathrm{~mm}$ were obtained by the pipette method. The sand fraction $(>0.05$ $\mathrm{mm}$ ) was separated by sieving. The $0.02-0.05 \mathrm{~mm}$ fraction was estimated as the difference between the sum of the different measured fractions expressed as $\mathrm{g} \mathrm{kg}^{-1}$.

Undisturbed samples were collected in duplicate using Kubiena boxes, at $0-0.1,0.3-$ $0.4,0.8-0.9$ and $1.5-1.6 \mathrm{~m}$ in each soil for thin section preparation. The undisturbed samples were impregnated under a suction of $5 \mathrm{kPa}$, with a polyester resin that was diluted with styrene monomer and left 4 weeks to ensure complete polymerisation. One thin section $45 \mathrm{~mm} \times 60 \mathrm{~mm}$ was made with every impregnated sample following the method of FitzPatrick (1984). They were polished with diamond grains of decreasing size and coated with carbon (Bruand et al., 1996). Thin sections were examined in scanning 
electron microscopy (SEM, Cambridge 90B) using the emission of backscattered electrons. The size distribution of microaggregates was determined using backscattered electron scanning images (BESI) taken at a magnification of 20x of samples collected at 1.5-1.6 m depth in NV2 and PA2. A total of ten BESI were used and between 180 and 230 individual microaggregates were delineated manually on every BESI. The surface area of microaggregates was determined using Visilog image analysis software (NOESIS, Velizy, France). Equivalent diameters were computed by assuming circular microaggregates. The results are presented as a distribution of the surface area occupied by microaggregates according to their equivalent diameter on BESI with associated standard deviation.

Cylindrical soil cores $1300 \mathrm{~cm}^{3}$ in volume were collected in triplicate from the $0-0.1$, 0.1-0.2 and 0.2-0.3 m layers. Between 0.3 and $1.6 \mathrm{~m}$ depth, they were collected in duplicate every $0.1 \mathrm{~m}$. The water content ranged from 0.18 to $0.26 \mathrm{~g} \mathrm{~g}^{-1}$ in the soils studied. The bulk density $\left(D_{\mathrm{b}}\right)$ was measured by weighing the soil within the $1300 \mathrm{~cm}^{3}$ cylindrical soil cores after oven-drying at $105^{\circ} \mathrm{C}$ for 60 hours. Then, the soil contained in every cylindrical soil core was sieved by dry sieving using a $0.84 \mathrm{~mm}$ meshed sieve, the smallest meshed sieve being able to separate the microaggregates. Because of great soil friability, the soil was sieved without any hand breaking prior sieving. Mechanical agitation with an horizontal movement was applied to the column of 5 sieves during 30 seconds (PRODUTEST, Brazil). For each depth, results are presented as the mean values of mass $\left(\mathrm{g} \mathrm{kg}^{-1}\right)$ and its range. The SAS ANOVA procedure was used to find significant differences between $D_{\mathrm{b}}$ at the $95 \%$ confidence level using a simple $\mathrm{t}$ test (SAS Institute, 1990).

\section{RESULTS AND DISCUSSION}

Visual assessment of BESI at low magnification showed areas with microaggregates in loose arrangement (Fig. 1a, c, d) and others where the aggregates were between 10 and $45 \mathrm{~mm}$ in size and included many multiconcave voids (Fig. 1b, c, d). Areas with aggregates 10 to $45 \mathrm{~mm}$ in size were numerous at the $0-0.4 \mathrm{~m}$ depth under native 
vegetation and pasture. Areas with microaggregates in loose arrangement were dominant in all horizons deeper than $0.5 \mathrm{~m}$, except in PA1 where they started to be prominent after $0.9 \mathrm{~m}$. In the first $0.1 \mathrm{~m}$ of PA1, the whole soil material corresponded to aggregates 10 to $45 \mathrm{~mm}$ in size in close arrangement.

Measurements on BESI from the deepest samples of soils NV2 and PA2 (1.5-1.6 m) revealed that 96.2 and $95.7 \%$ of microaggregates were smaller than $0.8 \mathrm{~mm}$, and 73.2 and $95.7 \%$ were between 0.1 and $0.5 \mathrm{~mm}$, respectively (Fig. 2). Thus, microaggregates were partly bigger than those described in other Brazilian Oxisols (e.g. Lima and Anderson, 1997; Furian et al., 1999; Neufeldt et al., 1999) and the sieved material < 0.84 $\mathrm{mm}$ can be used to estimate microaggregates proportion in the soil.

If we assume that before land clearing similar topographic locations have similar values of $D_{\mathrm{b}}$ at any depth, then NV1 can be compared with PA2, and NV2 with PA1 and PA3. There was no significant difference of $D_{\mathrm{b}}(\mathrm{P}=0.95)$ at any depth between NV1 and PA2 (Fig. 3a). Our results also showed a significant difference of $D_{\mathrm{b}}$ between NV2 and PA3 $(\mathrm{P}=0.95)$ at $0.1 \mathrm{~m}$ depth and then no significant difference deeper in the soil. The small $D_{\mathrm{b}}$ recorded at $0.1 \mathrm{~m}$ depth in NV2 would be related to presence of numerous biological channels as earlier recorded by Balbino et al. (2004) under native vegetation. Values of $D_{\mathrm{b}}$ were significantly greater at PA1 than at NV2 $(\mathrm{P}=0.95)$ at all depths from the surface to $1.3 \mathrm{~m}$ depth, and similar between 1.3 and $1.6 \mathrm{~m}$ depth. The lack of vertical variation in PA3 might be related to the youthfulness of the pasture (2 year-old pasture) compared to PA1 (13 year-old pasture). In this study, however, $D_{\mathrm{b}}$ was not systematically smaller under native vegetation than under pasture as suggested in earlier studies.

$D_{\mathrm{b}}$ was poorly correlated with clay content $\left(\mathrm{R}^{2}=0.36\right)$ and the texture was uniform across sites and with depth (Fig. $3 \mathrm{c}, \mathrm{d}, \mathrm{e}$ ). The increase in $D_{\mathrm{b}}$ shown in PA1 was related to the increase in macroaggregates development recorded by Tavares Filho (1995) in Oxisols of Southern Brazil. The greater $D_{\mathrm{b}}$ values in PA1 are related to a decrease in the proportion of material $<0.84 \mathrm{~mm}(\Phi<0.84)$ (Fig. 3b). Balbino et al. (2002b) discussed an 
increase in $D_{\mathrm{b}}$ in Oxisols of the same area as a decrease in microaggregates development when clearing the native vegetation for pasture.

Assuming no interaction between microaggregates and macroaggregates, the structure can be described as a combination of areas with microaggregates and those with macroaggregates at any depth. The volume of voids in the soil $\left(V_{\mathrm{v}}\right.$, in $\mathrm{cm}^{3}$ per $\mathrm{g}$ of soil oven-dried at $\left.105^{\circ} \mathrm{C}\right)$ can be written as follows:

$V_{\mathrm{v}}=\Phi_{<0.84} V_{\mathrm{v}, \mathrm{magg}}+\Phi_{>0.84} V_{\mathrm{v}, \mathrm{Magg},}$

where $V_{\mathrm{v}, \text { magg }}$ and $V_{\mathrm{v}, \text { Magg, }}$ are volume of voids of areas with microagregates and macroaggregates, respectively, and $\Phi_{<0.84}$ and $\Phi_{>0.84}$, are mass proportion of microaggregates and macroaggregates, respectively with:

$\Phi_{<0.84}+\Phi_{>0.84}=1$.

Combining equations (1) and (2), we obtain:

$V_{\mathrm{v}}=\Phi_{<0.84} \mathrm{~V}_{\mathrm{v}, \mathrm{magg}}+\left(1-\Phi_{<0.84}\right) V_{\mathrm{v}, \text { Magg }}$,

and thus:

$V_{\mathrm{v}}=\Phi_{<0.84}\left(V_{\mathrm{v}, \text { magg }}-V_{\mathrm{v}, \mathrm{Magg}}\right)+V_{\mathrm{v}, \mathrm{Magg}}$,

$\Phi_{<0.84}=\frac{\left(V_{\mathrm{v}}-V_{\mathrm{v}, \text { Magg }}\right)}{\left(V_{v, \text { magg }}-V_{v, \text { Magg }}\right)}$

Bulk density $\left(D_{\mathrm{b}}\right)$ is related to $V_{\mathrm{v}}$ as follows:

$V_{\mathrm{v}}=\left(\frac{1}{D_{\mathrm{b}}}\right)-V_{\mathrm{s}}$

Where $V_{\mathrm{s}}$ is specific volume of the solid phase in $\mathrm{cm}^{3}$ of solid per $\mathrm{g}$ of soil. Combining equations (3) and (4), we obtain:

$\Phi_{<0.84}=\left(\frac{1}{D_{\mathrm{b}}}\right) \cdot\left(\frac{1}{\left(V_{v, \text { magg }}-V_{v, \text { Magg }}\right)}\right)-\frac{\left(V_{\mathrm{s}}+V_{v, \text { Magg }}\right)}{\left(V_{v, \text { magg }}-V_{v, \text { Magg }}\right)}$

According to figure $2, \Phi_{<0.84}$ and $\Phi_{>0.84}$ can be estimated using the proportion of soil material respectively smaller and greater than $0.84 \mathrm{~mm}$.

Figure 4 shows that $\left(1 / D_{\mathrm{b}}\right)$ increased linearly with $\Phi_{<0.84}$ and the regression equation was: 
$\Phi<0.84=1.97 \cdot\left(\frac{1}{D_{\mathrm{b}}}\right)-1.52$

Then, according to equations (5) and (6), we obtain:

$\frac{1}{\left(V_{v, \text { magg }}-V_{v, \text { Magg }}\right)}=1.97$

and:

$\frac{\left(V_{s}+V_{v, \text { Magg }}\right)}{\left(V_{v, \text { magg }}-V_{v, \text { Magg }}\right)}=1.52$

Assuming $V_{\mathrm{s}}=0.38 \mathrm{~cm}^{3} \mathrm{~g}^{-1}$, reciprocal of the average particle density $2.65 \mathrm{~g} \mathrm{~cm}^{-3}$ that was determined by Balbino et al. (2002b) on similar soils, we obtain:

$V_{\mathrm{v}, \text { Magg }}=0.40 \mathrm{~cm}^{3} \mathrm{~g}^{-1}$

$V_{\mathrm{v}, \text { magg }}=0.90 \mathrm{~cm}^{3} \mathrm{~g}^{-1}$.

The porosity of microaggregates arrangement $\left(P_{\text {magg }}\right)$ and macroaggregates arrangement $\left(P_{\text {Magg }}\right)$ can be computed using $V_{\mathrm{v}, \text { magg }}$ and $V_{\mathrm{v}, \text { Magg }}$, respectively with:

$P_{\mathrm{magg}}=\frac{V_{\mathrm{v}, \mathrm{magg}}}{\left(V_{\mathrm{v}, \mathrm{magg}}+V_{\mathrm{s}}\right)}$

and

$P_{\text {Magg }}=\frac{V_{\mathrm{v}, \text { Magg }}}{\left(V_{\mathrm{v}, \text { Magg }}+V_{\mathrm{s}}\right)}$

Thus, we obtain:

$P_{\text {magg }}=0.71$

$P_{\text {Magg }}=0.51$.

The porosity resulting from the arrangement of microaggregates was $39 \%$ greater than for the macroaggregates. 


\section{CONCLUSIONS}

Our results showed that between 0 and $1.6 \mathrm{~m}$ depth in the Brazilian clayey Oxisols studied, the mass proportion of soil material $<0.84 \mathrm{~mm}$ was closely related to $D_{\mathrm{b}}$. Assuming that soil material $<0.84 \mathrm{~mm}$ corresponded to microaggregates throughout the soils studied, we also showed that the porosity resulting from the arrangement of microaggregates was much greater than for the aggregates $>0.84 \mathrm{~mm}$. Finally, our results showed that $D_{\mathrm{b}}$ at a given depth was not systematically greater under pasture than under native vegetation. As regards the latter point, the relationship recorded that uses $D_{\mathrm{b}}$ as easily accessible soil characteristic should enable a more accurate analysis of structural changes according to land use.

\section{REFERENCES}

Alexander, E.B. 1980. Bulk densities of California soils in relation to other soil properties. Soil Science Society of America Journal 44:689-692.

Balbino, L.C., A. Bruand, M. Brossard, and M.F. Guimarães. 2001. Comportement de la phase argileuse lors de la dessiccation dans les ferralsols microagrégés du Brésil : rôle de la microstructure et de la matière organique. Comptes Rendus de l'Académie des Sciences 332:673-680.

Balbino, L.C., M. Brossard, J.-C. Leprun, and A. Bruand. 2002a. Mise en valeur des Ferralsols de la région du Cerrado (Brésil) et évolution de leurs propriétés physiques : une étude bibliographique. Etude et Gestion des Sols 9:83-104. 
Balbino, L.C., A. Bruand, M. Brossard, M. Grimaldi, M. Hajnos, and M.d.F. Guimarães. 2002b. Changes in porosity and microaggregation in clayey Ferralsols of Brazilian Cerrado on clearing for pasture. European Journal of Soil Science 53:219-230.

Balbino, L.C., A. Bruand, I. Cousin, M. Brossard, P. Quetin, and M. Grimaldi. 2004. Change in the hydraulic properties of a Brazilian clay Ferralsol on clearing for pasture. Geoderma 120:297-307.

Bernoux, M., D. Arrouays, C. Cerri, B. Valkoff, and C. Jolivet. 1998. Bulk densities of brazilian Amazon soils related to other soil properties. Soil Science Society of America Journal 62:743-749.

Borges, E.N., F. Lombardi Neto, G.F. Correa, and E.V.S. Borges. 1999. Alterações físicas introduzidas por differentes níveis de compactação em Latossolo Vermelho-escuro textura média. Pesq. Agropec. Bras. 34(9):1663-1667.

Brossard, M., Lopes Assad, M. L., Chapuis Lardy, L., and Barcellos, A. O., 1997, Estoques de carbono em solos sob diferentes fitofisionomias de Cerrados, in Leite, L. L., and Saito, C. H., editors, Contribuição ao conhecimento ecológico do Cerrado. Trabalhos selectionados do $3^{\circ}$ Congresso de Ecologia do Brasil: Universidade de Brasília, Dep. Ecologia, p. 272-277.

Bruand, A., I. Cousin, B. Nicoullaud, O. Duval, and J.C. Begon. 1996. Backscattered electron scanning images of soil porosity for analyzing soil compaction around roots. Soil Science Society of America Journal 60:895-901.

Calhoun, F.G., N.E. Smeck, B.L. Slater, J.M. Bigham, and G.F. Hall. 2001. Predicting bulk density of Ohio Soils from Morphology, Genetic Principles, and Laboratory Characterization Data. Soil Science Society of America Journal 65:811-819.

Camargo, M. N., Kimble, J. M., and Beinroth, F. H., 1988, Classification, characterization and utilization of Oxisols, Proceeding of the eight international soil classification workshop, Rio de Janeiro, Brazil, 12 to 23 May 1986: Rio de Janeiro-RJ, Empresa Brasileira de Pesquisa Agropecuária.

Camargo, O. A., Moniz, A. C., Jorge, J. A., and Valadares, J. M. A. S., 1986, Méthodos de análise química, mineralógica e física de solos do Instituto Agronómico de Campinas: B. Técn. Inst. Agron., v. 106: Campinas, 94 p.

Curmi, P., Kertzman, F. F., and Queiroz Neto, J. P., 1992, Degradation of Structure and hydraulic properties in an Oxisol under cultivation (Brazil), in Ringrose-Voase, A. J., and Humphreys, G. S., 
editors, Proceedings of the IX International Working Meeting on Soil Micromorphology: Townsville, Australia, International Society of Soil Science, p. 569-579.

Desjardins, T., E. Barros, M. Sarrazin, C. Girardin, and A. Mariotti. 2004. Effects of forest conversion to pasture on soil carbon content and dynamics in Brazilian Amazonia. Agriculture, Ecosystems \& Environment 103:365-373.

Embrapa. 1999. Centro Nacional de Pesquisa de solos (Rio de Janeiro, RJ). Sistema brasileiro de classificação de solos Embrapa Produção de Informação, Embrapa Solos, Basília, DF.

FitzPatrick, E.A. 1984. Micromorphology of Soils Champman \& Hall, London.

Freitas-Silva, F.H., and J.E.G. Campos. 1998. Geologia do Distrito Federal, In IEMA/SEMATEC/UnB, ed. Inventário Hidrogeológico e dos Recursos Hídricos Superficiais do Distrito Federal, Vol. 1, Parte 1. IEMA/SEMATEC/UnB., Brasília.

Furian, S., L. Barbiéro, and R. Boulet. 1999. Organisation of the soil mantle in tropical southeastern Brazil (Serra do Mar) in relation to landslides processes. Catena 38:65-83.

Kondo, M.K., and M.S. Dias Junior. 1999. Efeito do manejo e da umidade no comportamento compressivo de três latossolos. Revista Brasileira de Ciência do Solo 23:497-506.

Lilienfein, J., W. Wilcke, M.A. Ayarza, L. Lima, L. Vilela, and W. Zech. 1999. Annual course of matric potential in differently used savannah Oxisols in Brazil. Soil Science Society of America Journal 63:1778-1785.

Lima, J.M., and S.J. Anderson. 1997. Aggregation and aggregate size effects on extractable iron and aluminium in two hapludoxs. Soil Science Society of America Journal 61:965-970.

Manrique, L.A., and C.A. Jones. 1991. Bulk density of soils in relation to soil physical and chemical properties. Soil Science Society of America Journal 55:476-481.

Neufeldt, H. 2001. Physical and Chemical Properties of Selected Oxisols in Brazilian Cerrados, p. 37-50, In R. Thomas and M. A. Ayarza, eds. Sustainable Land Management for the Oxisols of the Latin American Savannas: Dynamics of Soil Organic Matter and Indicators of Quality. Centro Internacional de Agricultura Tropical, Cali, Colombia.

Neufeldt, H., M.A. Ayarza, D.V.S. Resck, and W. Zech. 1999. Distribution of water-stable aggregates and aggregating agents in Cerrado Oxisols. Geoderma 93:85-99. 
Neves, C.S.V.J., C. Feller, M.F. Guimaraes, C.C. Medina, J. Tavares Filho, and M. Fortier. 2003. Soil bulk density and porosity of homogeneous morphological units identified by the Cropping Profile Method in clayey Oxisols in Brazil. Soil and Tillage Research 71:109-119.

Prévost, M. 2004. Predicting Soil Properties from Organic Matter Content following Mechanical Site Preparation of Forest Soil. Soil Science Society of America Journal 68:943-949.

Rawls, W.J. 1983. Estimating soil bulk density from particle size analysis and organic matter content. Soil Science 135:123-125.

SAS Institute, 1990. SAS/STAT users guide. Version 6.SAS Institute, Cary, NC.

Soil Survey Staff. 1996. Keys to Soil Taxonomy USDA-NRCS, Washington.

Stone, L.F., and P.M. Da Silveira. 1978. Conductividade hidráulica de um latossolo vermelho-amarelho. Pesq. Agropec. Bras. 13:63-71.

Tavares Filho, J., 1995, Organisation et comportement de Latosols du Parana (Brésil). Influence de leur mise en culture: Nancy (France), Université de Nançy I, p. 232.

Tavares Filho, J., and D. Tessier. 1998. Influence des pratiques culturales sur le comportement et les propriétés de sols du Paraná (Brésil). Etude et Gestion des Sols 5:61-71. 


\section{Figure captions}

Fig. 1. Examples of Backscattered Electron Scanning Images (BESI) illustrating soil structural features of soils sampled from native vegetation (NV2) and pasture (PA2, PA3) sites: a) microaggregates at 1.5-1.6 m (NV2), b) macroaggregates with multiconcave voids at 0.3-0.4 m (PA2), and macroaggregates associated with microaggregates at c) 1.5$1.6 \mathrm{~m}$ (NV2), and d) 0.3-0.4 m (PA3). Black areas are voids, light gray areas are quartz or oxide grains, and darker gray areas correspond to porous clay. Scale bar: $2 \mathrm{~mm}$.

Fig. 2. Microaggregate size distribution measured on Backscattered Electron Scanning Images (BESI) of soil sampled at 1.5-1.6 m depth from soil a) under native vegetation (NV2), and b) under pasture (PA2). Bars represent standard deviations.

Fig. 3. Soil properties as a function of depth: a) bulk density, b) proportion of mass fraction $<0.84 \mathrm{~mm}$, and fraction of c) clay, d) silt, and e) sand content. Bars represent the largest and the smallest values.

Fig. 4. The inverse of bulk density $\left(1 / D_{\mathrm{b}}\right)$ as a function of the mass proportion of soil material $<0.84 \mathrm{~mm}\left(\Phi_{<0.84}\right)$ for all the soils. The solid line is the linear regression of $\Phi_{<0.84}$ against $\left(1 / D_{\mathrm{b}}\right)$. 
Figure 1
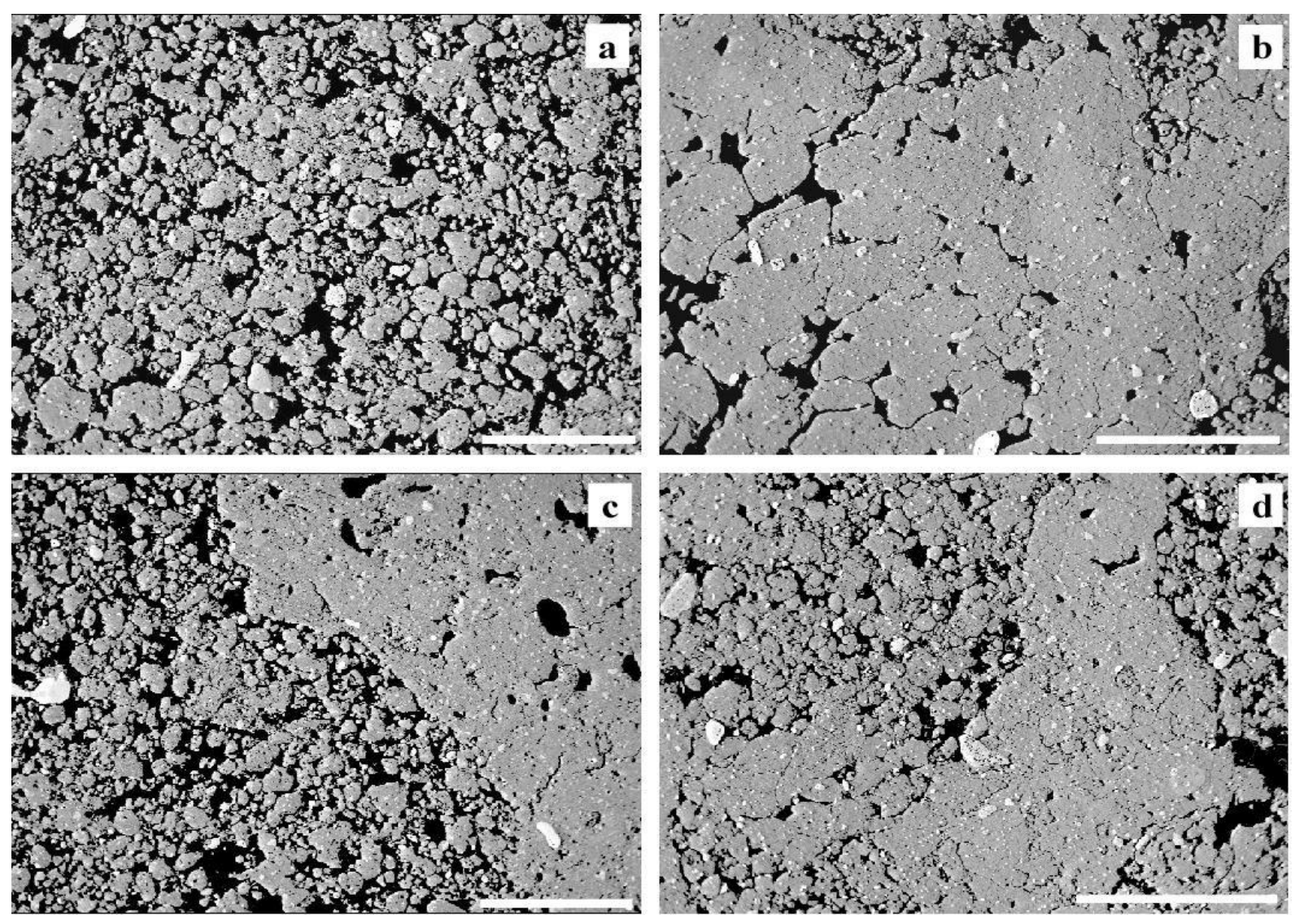
Figure 2

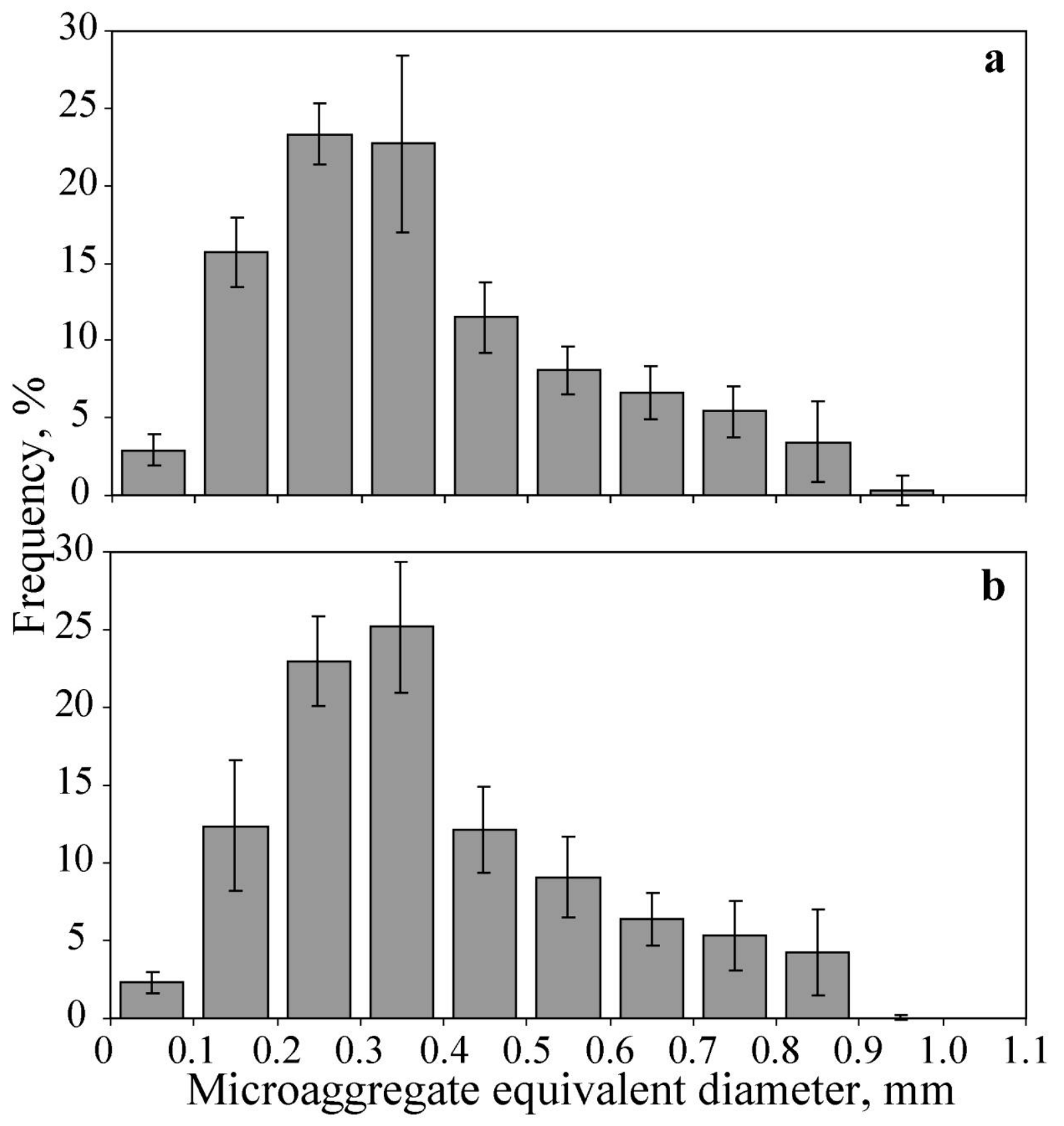


Figure 3
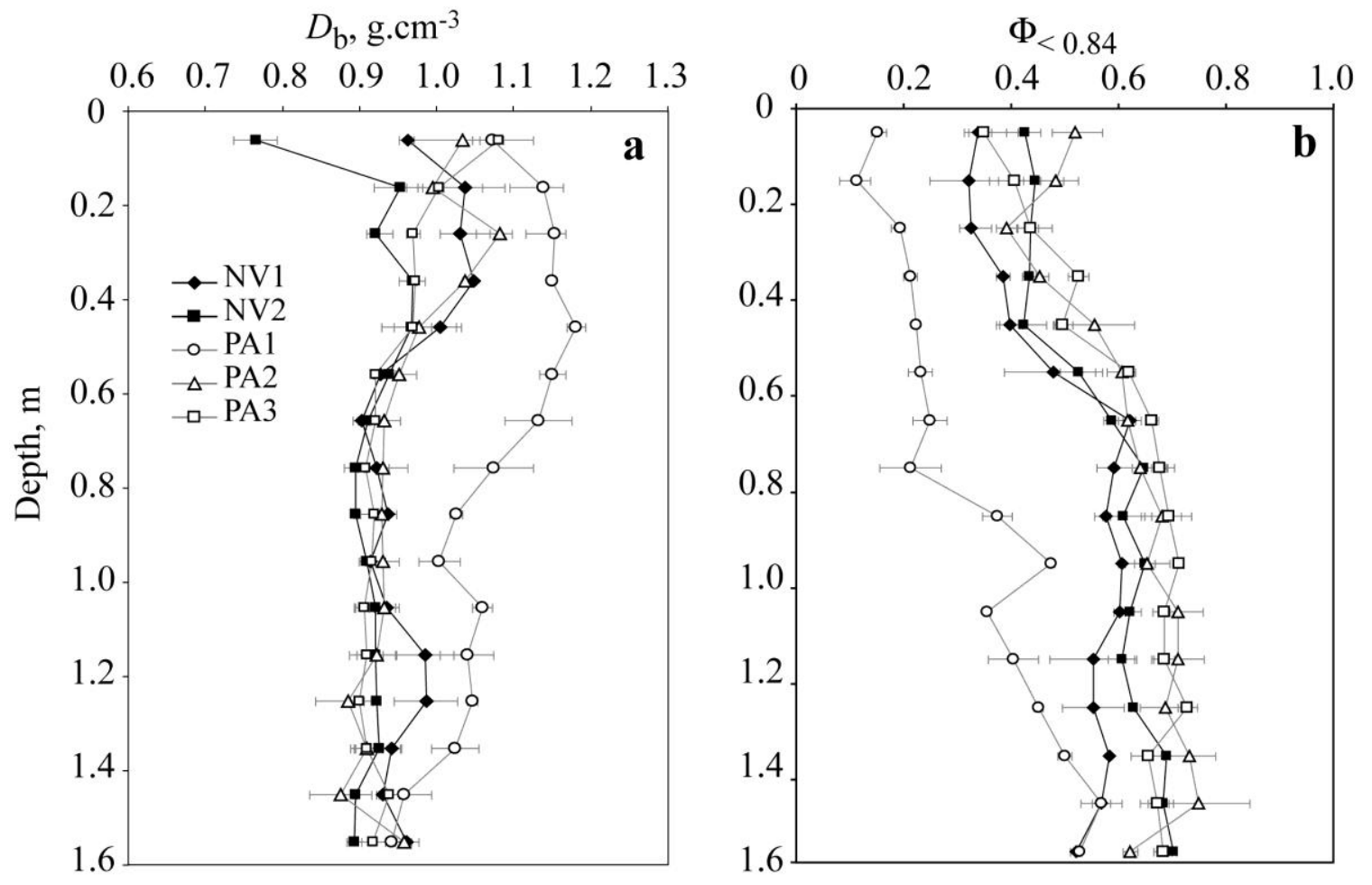

Clay content, g.kg-1

Silt content, g.kg-1

Sand content, g.kg-1
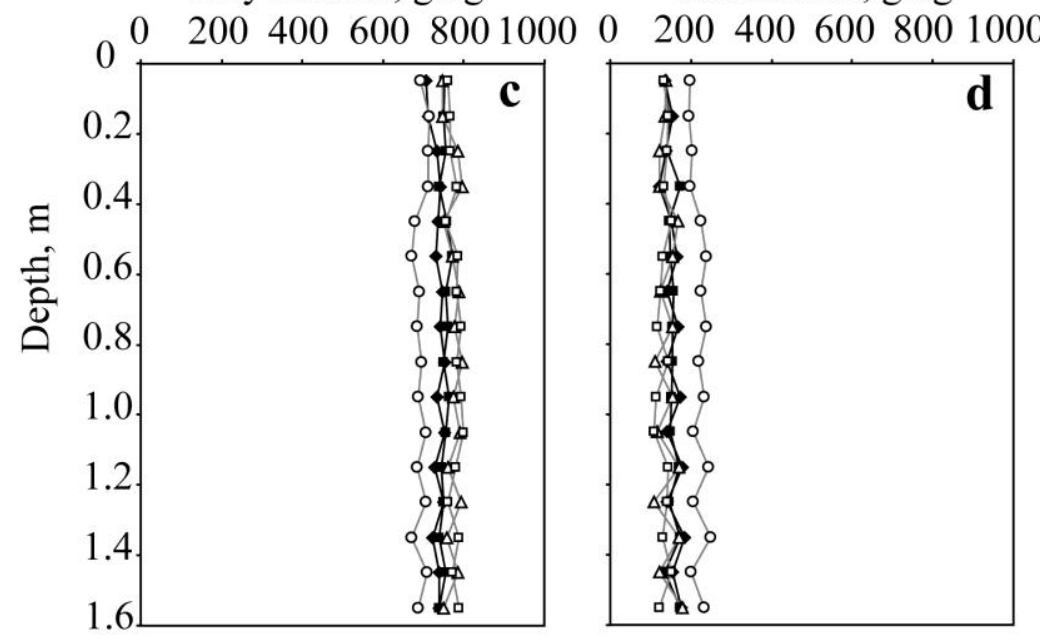

$0 \quad 2004006008001000$

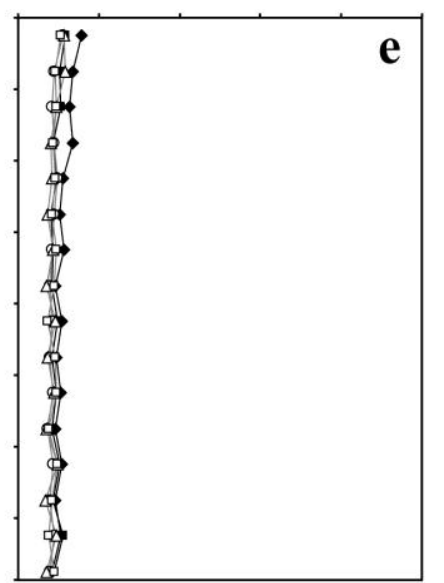


Figure 4

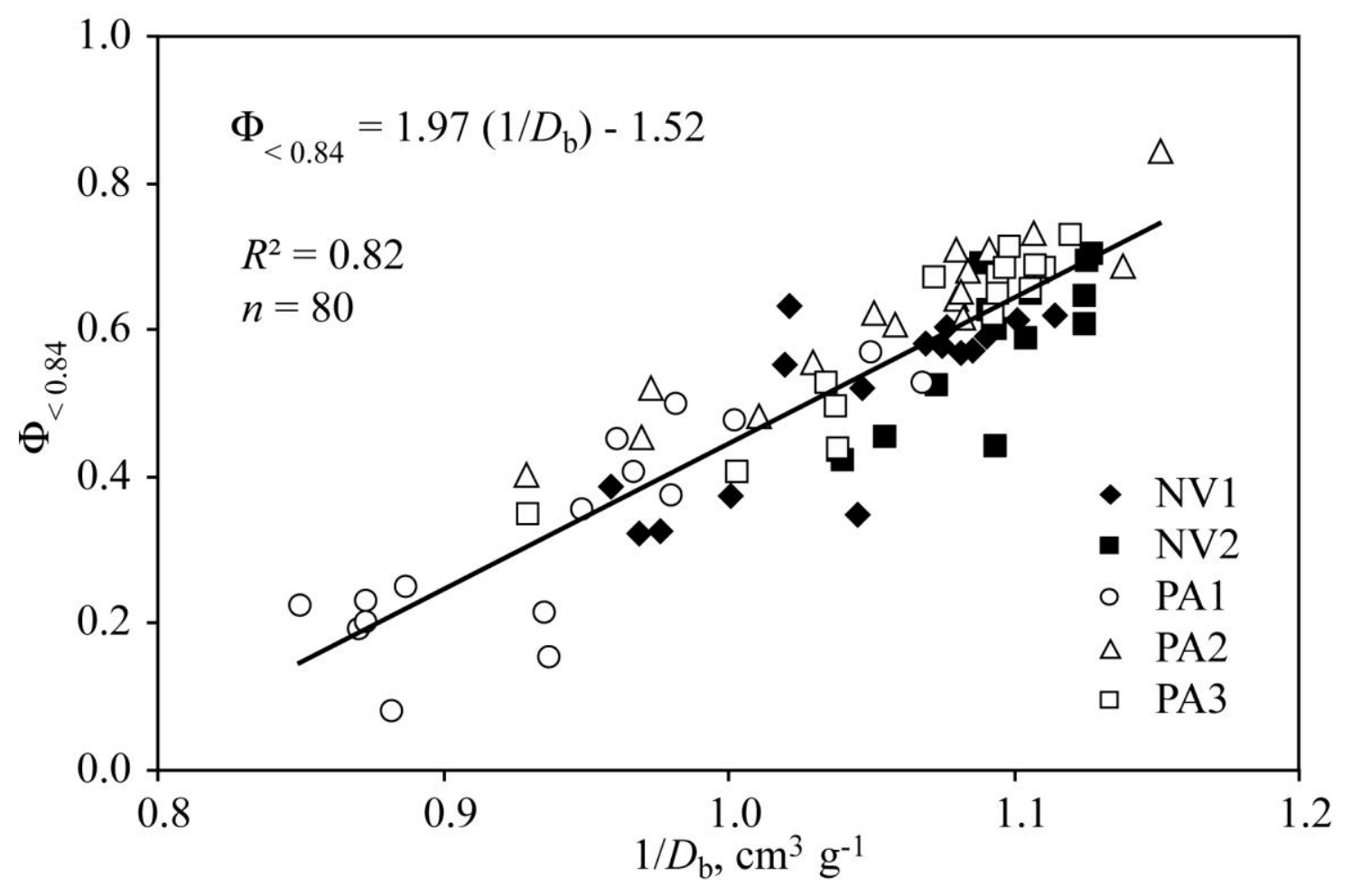

